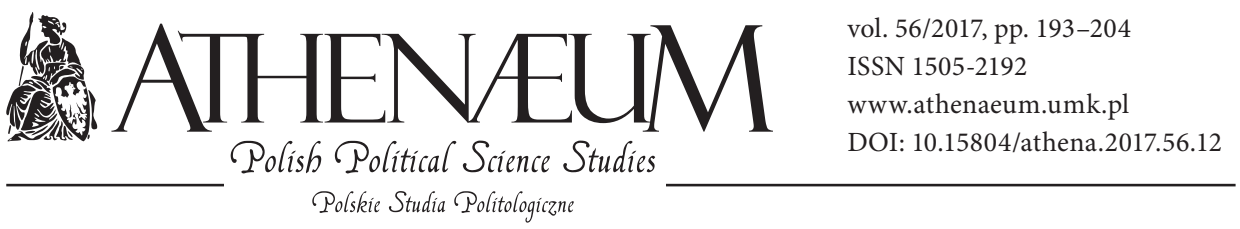

\title{
INTERNATIONAL RISK FACTORS OCCURRING IN THE CASPIAN SEA REGION
}

\author{
CZYNNIKI RYZYKA MIĘDZYNARODOWEGO WYSTĘPUJĄCE \\ W REGIONIE MORZA KASPIJSKIEGO
}

Joanna Piechowiak-Lamparska*

\begin{abstract}
From the perspective of structural realism, the category of international risk can be defined as a possibility of a sudden and unexpected change which may lead to negative outcomes. The aim of the article is to analyze and show international risk factors present in the Caspian Sea region. In the context of various variables of geostrategic character, the region seems prone to potential threats. The research applied the method of the analysis of strategic narratives, which made it possible to distinguish the most important risk factors in the context of the policy followed by global and regional superpowers: 1) political factors and international strategy; 2) extracting energy resources and the geopolitics of pipelines; 3) frozen territorial and ethnic conflicts; 4) economic factors; 5) military factors. The results show that for the majority of players the lack of stability is beneficial and they do not strive to solve the contentious issues at all costs.
\end{abstract}

Kategoria ryzyka międzynarodowego $\mathrm{z}$ perspektywy realizmu strukturalnego może być zdefiniowana jako możliwość wystąpienia nagłej i nieoczekiwanej zmiany o negatywnych konsekwencjach. Celem artykułu jest analiza i wskazanie czynników ryzyka międzynarodowego obecnych w regionie Morza Kaspijskiego, który w kontekście syntezy wielu zmiennych o charakterze geostrategicznym wydaje się być podatny na występowanie potencjalnych zagrożeń. W badaniach zastosowano metodę analizy narracji strategicznych, która pozwoliła na wyodrębnienie najważniejszych czynników ryzyka w kontekście polityki mocarstw globalnych i regionalnych: 1) czynniki polityczne i strategia międzynarodowa; 2) wydobycie surowców energetycznych i geopolityka rurociągów; 3) zamrożone konflikty etniczne i terytorialne; 4) czynniki ekonomiczne; oraz 5) czynniki militarne. Wyniki wskazują, że dla większości graczy brak stabilizacji jest korzystny i nie dążą oni do rozwiązania spornych kwestii za wszelką cenę.

* Nicolaus Copernicus University in Toruń, Faculty of Political Sciences and International Studies; research fellow at Grigol Robakidze University in Tbilisi, Georgia. 
Keywords: international risk, risk factors, postSoviet area, the Caspian Sea region, the South Caucasus, the superpowers great game
Słowa kluczowe: ryzyko międzynarodowe, czynniki ryzyka, obszar poradziecki, region Morza Kaspijskiego, Kaukaz Południowy, wielka gra mocarstw

\section{INTRODUCTION}

Risk is a threat that something unexpected will happen and possibly cause damage. In research on international relations risk can be described as a possibility of a sudden and abrupt change which may (but not necessarily will) lead to negative outcomes. In the theory of international relations, risk is not considered as equivalent to danger, but precisely to the possibility of its occurrence (Demir, 2017; Berejikian, 2016). The factors contributing to the occurrence of risk in the international sphere can be divided and categorized in various ways. However, it seems that the most relevant approach to research on the post-Soviet area is the one based on the paradigm of structural realism whose main focus rests on political, economic, and military factors in their different configurations (Bishop, 2014; Clapton, 2011). Undoubtedly, another element worth noting is the social factor characteristic of constructivist analysis; however, the research approach adopted here intends to analyse the factors precisely on the level of international structure which includes "hard" realist security frame.

The aim of the analysis presented in this article is to show risk factors present in the Caspian Sea region and to group them by major categories. The text is of analytical character and its objective is to create a multilevel image of the broadly understood Caspian area (Aburas, Demirbas, 2015). The factors which were analysed here and considered the most influential ones include political factors and international strategy, fuel output and geopolitics of pipelines, frozen conflicts as well as military and economic factors in the context of the participation of global and regional superpowers (Bahgat, 2002). The selection of factors stems from the application of the method based on the analysis of strategic narratives in and about the region. According to Roselle, Miskimmon, and O'Loughlin (2017; 2014), the concept of the analysis of strategic narratives is based on describing events in three major dimensions: formation, projection, and reception.

The players in the Caspian region, due to their geographical and geostrategic location along with their international position, create their own strategic narratives (De Graaf, Dimitriu, Ringsmose, 2015), yet they also become the elements 
of and exist in the narratives of other players such as the USA, China, NATO, and the European Union. The article offers description of the Caspian Sea region and presents factors, derived from strategic narratives, which contribute to the occurrence of risk. The research process involved analyzing documents on strategy and external policy of the states in the region as well as other states or international organizations which pursue their interests there.

\section{CHARACTERISTIC OF THE CASPIAN SEA REGION}

The Caspian Sea region is diverse in many respects. Moreover, the list of states which consider themselves to belong to the region remains a problematic issue. There are two approaches which can be distinguished here: 1) the narrow one, in which only the states that have access to the sea: that is, Russia, Kazakhstan, Turkmenistan, Azerbaijan, and Iran belong to the Caspian region; or 2) the broad one, which includes also Georgia and Armenia as these states are of considerable transit potential. The article adopts the extended list of the states since it more adequately embodies the geostrategic image of the region.

As a result of the dissolution of the Soviet Union, the situation in the Caspian region has changed radically. Firstly, there has been an increase in the number of states with access to the sea, and the agreements on the legal status of the Caspian Sea concluded between the USSR and Iran have become void. Secondly, the presence of new players in the region has shaken the balance there, particularly due to the possibility of unfreezing the conflicts between them. Thirdly, the region has become open to cooperation with powerful players from the outside of the system in which the USSR held all the cards (Humphrey, Skvirskaja, 2014). Undoubtedly, in the last quarter of a century, the geopolitical situation in the Caspian region as well as the map of relations and connections between the players have undergone many changes.

Currently, it is possible to distinguish several groups of subjects which shape the relations in the region and actively participate in the game. First of all, the state which is pursuing its vital interests in the region is Russia, which is building its sphere of influence by long-standing agreements on individual output and transport of fuels as well as by buying them from others (Russia is still the biggest producer and exporter of fuels in the region). Moreover, it is worth noting that Russia is initiating, planning and promoting the establishment of international structures such as the Eurasian Economic Union (whose members 
are Kazakhstan and Armenia). Russia regards the Caspian region as its direct sphere of influence and maintains it by skilful use of some frozen conflicts such as the conflict in Nagorno-Karabakh between Azerbaijan and Armenia, or the separatist tendencies of Abkhazia and South Ossetia. The process aiming at destabilization of the region and closing it to the influences of Western players has repeated several times.

As a matter of fact, it is the group of external Western players which constitutes the second important group pursuing its interests in the Caspian Sea region. This group comprises the member states of the European Union which seek diversification of the supply of energy fuels, and more precisely, which want to become independent from Russia's supplies and its fuels policy (Babayan, 2016). An important part is played also by the United States, which since the dissolution of the Soviet Union has been trying to expand its sphere of influence in the near abroad states and limit Russian potential by using such instruments as strategic partnership with the states in the region or support for the BTC oil pipeline and the Baku-Erzurum gas pipeline (Austvik, Rzayeva, 2017). In 2013, the Committee on Foreign Affairs said that "successive United States Administrations supported development of energy resources in the Caspian Sea region, including construction of the landmark Baku-Tbilisi-Ceyhan oil pipeline and Baku-Tbilisi-Erzurum gas pipeline that are main arteries delivering Caspian energy resources to global markets" and, in consequence, "the priority now becomes the realization of the Southern Gas Corridor to deliver additional volumes of natural gas from the Caspian Sea region to European markets" (H. RES. 284). It is important to mention here the attempts made by Georgia, and earlier also Armenia, to engage in close cooperation with NATO and the European Union. The project has been partially successful as despite the consequences of the Russian-Georgian War of 2008, Georgia signed the Association Agreement with the EU in 2015 and is still cooperating with NATO. The involvement of the EU is also reflected in the creation of the EU-US Energy Council during the 2009 summit.

Despite being limited by long-standing agreements with Russia, Azerbaijan is still a relatively independent player. This state, besides having a direct access to energy deposits, is trying to define its role by exploiting the transit potential and the possibilities of building new pipelines. Azerbaijan is also a part of a Chinese international project - the New Silk Road. As a consequence of numerous conflicts and animosities between the states in the region, a lot of plans have failed, for instance, the Nabucco project. 


\section{FACTORS CONTRIBUTING TO THE OCCURRENCE OF INTERNATIONAL RISK}

\section{Political factors}

Geopolitical factors play an important part in shaping the image of the Caspian region. This is a territory where a lot of players pursue their vital interests. Changing the Russian lake into a region which is geostrategically interesting for the USA, China, Turkey, or the European states has made the Caspian Sea region worth competing for. First of all, the political risk is connected here with competing interests of the post-Soviet states, Iran, and the Western players (Saparov, 2014).

It seems that the major factor which attracts attention of superpowers is the energy resources; however, another important factor lies in the tug-of-war policy and the strategy of building one's sphere of influence on the post-Soviet territory, which is followed mainly by the USA, as direct influence on the states in the region may deprive Russia of some part of its influences and weaken its position as the regional superpower. The Caspian Sea is important for Russia not only due to fuel output and transport of energy resources, but it also has considerable significance to its image (Maass, 2016).

\section{Extracting energy resources and the geopolitics of pipelines}

The Caspian Sea region is an important part of the world market of energy resources, especially due to its rich deposits of natural gas and crude oil. As Bahgat (2002) suggested, in order to use these resources effectively and make them an effective tool in international politics, the region should deal with four major issues. It is worth noticing that after 15 years, the identified problems are still present.

The first issue concerns thorough and accurate assessment of the deposits of resources as well as establishment of borders on the Caspian Sea that would be respected (Zonn, 2015). Yet in 2017, the border issues between Azerbaijan and Iran have not been resolved, and the reserves have not been estimated, especially in the Iranian and Turkmen parts. The second issue is something of a rivalry between the states in the region and the superpowers which aspire to extend their spheres of influence by controlling the extraction of energy resources along with their further transport and sale. The problem is multidimensional 
and involves long-standing trade agreements, strategies on energy, ecological issues of the Caspian Sea basin, and the need for diversification of fuel supplies (Naghizadeh, Farshchi, Karimi, Mirabbasi, 2016). On the one hand most of the Caspian resources at the stage of their extraction and transport is controlled by Russian energy companies (also by using agreements which oblige other states, e.g. Kazakhstan, not to cross the oil and gas sales limits); on the other hand, there are new traders, such as China or the British company BP who are ready to invest in new transport corridors. The third issue involves frozen ethnic problems, which are discussed in detail hereafter. These problems are still unsolved, which can destabilize the region in short time. The last issue influencing the exploitation of resources is the lack of appropriate transport corridors, and the need for modernization of extraction technologies. The most important and most ergonomic pipelines in the region are used by Russian energy companies (Eldarov, Holland, Kamilov, 2015). The fall of the Nabucco-West pipeline project shows that cooperation between the states in the region will require from them a lot of work and effort. This effort is also necessary for solving and finishing the inveterate ethnic, religious, and territorial conflicts (Kubicek, 2013).

\section{Frozen conflicts}

The Caspian region is characterized by high instability caused by the constant possibility of resuming frozen conflicts. The most important of them, and those which have reoccurred in the recent years, include the conflicts in the South Caucasus, Nagorno-Karabakh, Abkhazia, and South Ossetia. Moreover, there are independence movements in Chechnya, Dagestan, Karachay-Cherkessia, and Kabardino-Balkaria, i.e. in the North Caucasus, which belongs to the Russian Federation.

The War in Nagorno-Karabakh has been the reason of conflict between Armenia and Azerbaijan since the 1980s. The unregulated status of the NagornoKarabakh Republic is at the root of the lack of cooperation between the two states. This is a military conflict of ethnic character which has been going on regularly since 1994. Until today, there have been fights and incidents along the demarcation line. Russia's engagement in the conflict is also of great importance. The state has sympathized with Armenia and in this way partially controls the situation. The high tension was clearly reflected in the exacerbation of the conflict in April 2016 (Geukjian, 2016; Blank, 2015). 
The biggest military conflict between the players in the region of the South Caucasus was the Russian-Georgian War in 2008. As a result of the war, two rebellious provinces - Abkhazia and South Ossetia - separated from Georgia and proclaimed independence. The conflicts caused by long-standing, unresolved disputes of ethnic origin led to the loss of territorial integrity of Georgia and influenced the process of European and Euroatlantic integration in the region. It is believed that the Russian engagement was a response to the attempt of Western players to extend their sphere of influence in the Caucasus (German, 2016). In consequence, the NATO-Russia Council was suspended for several months and the member states of the EU imposed sanctions against Russia (Freizer, 2017; Saparov, 2014). There is no doubt, however, that establishing the free trade zone between Russia and Abkhazia as well as Russia and South Ossetia can be understood as an informal annexation of the separatist republics by Russia.

\section{Economic factors}

The economic issues in the Caspian region are strongly connected with international and energy policy. The states in the region, which came into existence after the dissolution of the Soviet Union - i.e. Russia, Kazakhstan, Turkmenistan, Azerbaijan, Georgia, and Armenia - are developing unevenly, which causes substantial stratification. Despite the economic crisis, the best economic indicators are achieved by Russia, which compensates for the slowdown in the level of economic growth by remaining the most important trade partner for the states in the post-Soviet territory. Russia reaches its economic goals in the Caspian region by economic integration achieved on many levels. One of the principal methods of exerting economic influence is using instruments causing dependence, for example, in the area of sale and transport. Russian foreign policy is also characterized by its use of instruments typical of structural powers - it initiates and controls establishing international organizations. It is worthwhile to mention the functioning of the Commonwealth of Independent States, the Eurasian Economic Community, the Customs Union, and the Common Economic Space. Thanks to a number of connections, Russia has the ability of causing economic destabilization in the Caspian region. The level of risk is clearly influenced by both the value of trade exchange and cooperation in strategic sectors, such as the sectors of energy or defence (Heinrich, Pleines, 2015). 
The level of economic risk in the region is visible in the Russian-Iranian relations. Both Russia and Iran feel the effects of price fluctuations on the energy resources market; however, the long-standing sanctions against Iran imposed by the USA and the EU member states led to increased economic cooperation between the two states. Iranian demand for Russian goods caused a kind of economic dependency and despite the progress in unfreezing the AmericanIranian relations, the ones between Moscow and Tehran still remain very close. The states cooperate mainly in the energy sector; however, their cooperation in trade exchange is also clearly visible (in March 2017 there were talks on establishing a free trade zone between the Eurasian Economic Community and Iran). Moreover, Russia and Iran are allies in the Syrian conflict and show mutual support on the international arena.

\section{Military factors}

Undoubtedly, it is Russia which remains the military hegemonic leader in the region as it has the largest military forces on the Caspian Sea and in the region of the North Caucasus. It is important to say that thanks to its developed net of connections, the state has subdued a part of the region of the South Caucasus: Armenia, which receives Russian support in the conflict over Nagorno-Karabakh, as well as Abkhazia and South Ossetia, which without Russia are unlikely to maintain sovereignty (Jafarova, 2014). Nevertheless, the Caspian Flotilla, which is still partially based on the units that served in the USSR army, is continuously modernized and its combat and defence readiness is strengthened (it has at least 3 Buyan-M missile corvettes). This means that in case of military conflict in the Caspian Sea basin, the Russian navy would have a definite advantage. Moreover, the military port in Kaspiysk in Dagestan which is to open in 2020 will be Russia's another chief asset. This important military facility will be the main, the largest, state-of-the-art naval base in the Russian Navy and in the Caspian region.

The second place is occupied by the Iranian Flotilla, which has, however, much lower combat value than the Russian Flotilla. Despite building new destroyers and submarines, Iran is largely equipped with older vessels (Rabiee, GharehBeygi, Mousavi, 2015; Robert, Letouzey, Kavoosi, Sherkati, Müller, Vergés, Aghababaei, 2014). Yet Iran has still much better military position on the sea than Azerbaijan, Kazakhstan and Turkmenistan. Their weaponry comes mostly from the USSR times and the states began the process of modernization 
relatively late as it has been carried out since 2000. Moreover, Azerbaijan has a modern (opened in 2015) naval base in Puta. The military security architecture of the Caspian Sea basin does not allow ships which are not under the flag of the littoral states to sail. Besides the states take part in joint military exercises. It seems that maintaining military stability is the goal of all the states; however, the asymmetry of power in this respect shows that the occurrence of risk is possible, for example, in case of violation of the borders of internal waters.

\section{TROUBLE SPOTS: THE GREAT GAME OF SUPERPOWERS IN THE CASPIAN REGION}

First of all, it should be emphasized that rivalry between great players leads to consequences for both the Caspian region and individual players. While Russia and the USA compete for their sphere of influence and the EU makes attempts to diversify the energy resources supplies, most of the states in the region follow multi-vector policy (Włodkowska-Bagan, 2013). It is difficult to say explicitly whether the policy of balance and manoeuvring between superpowers and their interests is effective; however, turning into only one direction seems risky (Freizer, 2017).

Both Russia and the USA skilfully manipulate risk factors. Their use of energy policy as a tool for distributing limited goods (energy resources) results in building dependencies, which is a factor contributing to the situation of permanent risk. On the other hand, the USA has used sanctions against Russia or Iran as powerful instruments. Such policy was one of the reasons for isolation of Iran, which in consequence strengthened their cooperation with Russia. One of the important aspects facilitating stability in the region was the strategy of Euro-Atlantic and European integration by using the instruments of strategic partnership (Stent, 2015; Tsygankov, 2014).

The analysis showed that in the $21^{\text {st }}$ century the trouble spots mainly include 1) strategies of superpowers which treat the Caspian region as a field where they play the game for their sphere of influence, which means instrumental treatment of the states in the region; 2) economic stratification, which may lead to a conflict based on the shortage of goods; 3 ) insufficient diversification in energy policy as well as conflict-provoking geopolitics, pipelines location and transport corridors; 4) frozen and regularly resumed territorial and ethnic conflicts (mainly the conflicts in Nagorno-Karabakh, Abkhazia, and South Ossetia, but also the lack 
of fixed borders and ownership of some of the gas and oil fields on the Caspian Sea); 5) military rivalry on the Caspian Sea, which is reflected in an increasingly intensive arms race. The presented list of factors does not exhaust the issue of risk occurrence in the region, but these factors are the most visible potential threats.

\section{SUMMARY}

The Caspian Sea region is in many respects a unique territory. It is worth noting that most of possible factors contributing to the occurrence of international risk are present there. Risk means a possibility, not a certainty, of danger which leads to damage. The analysis of strategic narratives showed that there is a possibility of the occurrence of risk caused by geopolitical factors, so mainly by the rivalry between superpowers on this territory. The issue of rivalry over the sphere of influence - the region rich in energy resources, has been a current problem in international politics since the dissolution of the Soviet Union. At the beginning, in the first phase, the Caspian region remained in the Russian sphere of influence; however, at the turn of the $20^{\text {th }}$ and $21^{\text {st }}$ century, Western players such as the USA, the EU, and NATO joined the game (Smith, Twardowski, 2017; Stent, 2015).

In order to find the answer to the research question regarding possible and major reasons for the occurrence of international risk in the Caspian region, it is worthy to find the most frequent factor. In the case discussed here, this factor involves extracting energy resources and the geopolitics of pipelines, which influences and is also directly connected with economic and military factors. The possibility of resuming frozen conflicts constitutes an additional element that constructs the picture of the region. The analysis of narrative shows that for the majority of players the status of "unstable stability" is beneficial so they do not strive to solve the contentious issues at all costs.

The results presented in the article do not exhaust theoretical problems concerning the occurrence of international risk and the analytical issues relating to the Caspian Sea region. It seems, however, that they are a good starting point for solving the issue concerning the factors which determine the occurrence of international risk in general. It is also advisable for future research to compare the results regarding the Caspian region with the ones concerning Central Europe. Moreover, the clearly visible rivalry between superpowers makes the risk factors alternate with frozen as well as new conflicts, and with the influence of the current international situation. 


\section{REFERENCES:}

Aburas, H., Demirbas, A. (2015). The Caspian Sea Basin, Middle East Petroleum Resources, and the Importance of Turkey. Petroleum Science and Technology, 33(4), 397-405.

Austvik, O.G., Rzayeva, G. (2017). Turkey in the geopolitics of energy. Energy Policy, $107,539-547$.

Babayan, N. (2016). A Global Trend EU-style: Democracy Promotion in 'Fragile'and Conflict-Affected South Caucasus. Global Policy, 7(2), 217-226.

Bahgat, G. (2002). Pipeline Diplomacy: The Geopolitics of the Caspian Sea Region. International Studies Perspectives, 3(3), 310-327.

Berejikian, J.D. (2016). David versus Goliath: Risk and Weaker State Confrontation. Foreign Policy Analysis, orw037.

Bishop, E. (2014). Neglected resistance: Counter-conducts and neoliberal governmentality through risk in International Relations. CISD Yearbook of Global Studies, 1(1), 229-251.

Blank, S. (2015). US Policy, Azerbaijan, and the Nagorno-Karabakh Conflict. Mediterranean Quarterly, 26(2), 99-114.

Clapton, W. (2011). Risk in international relations. International Relations, 25(3), 280-295.

De Graaf, B., Dimitriu, G., Ringsmose, J. (2015). Conclusion: How to operate strategic narratives. Interweaving war, politics, and the public. In Strategic Narratives, Public Opinion, and War (pp. 351-366). Routledge.

Demir, I. (2017). Modeling the Relationship Between Past Outcomes, Overconfidence and Risk Taking. In Overconfidence and Risk Taking in Foreign Policy Decision Making (pp. 19-39). Springer International Publishing.

Eldarov, E.M., Holland, E.C., Kamilov, M.K.B. (2015). Oil and Gas Production in the Russian Sector of the Caspian Sea: Public Opinion on Development Paths and Consequences. The Professional Geographer, 67(3), 342-350.

Freizer, S. (2017). The revised European Neighbourhood Policy and conflicts in the South Caucasus: The EU's growing conflict transformation role. In The Revised European Neighbourhood Policy (pp. 157-176). Palgrave Macmillan UK.

German, T. (2016). Regional Cooperation in the South Caucasus: Good Neighbours Or Distant Relatives?. Routledge.

Geukjian, O. (2016). Ethnicity, nationalism and conflict in the South Caucasus: NagornoKarabakh and the legacy of Soviet nationalities policy. Routledge.

H.Res.284 - Expressing the sense of the House of Representatives with respect to promoting energy security of European allies through opening up the Southern Gas Corridor. https://www.congress.gov/bill/113th-congress/house-resolution/284/text.

Heinrich, A., Pleines, H. (2015). Mixing geopolitics and business: How ruling elites in the Caspian states justify their choice of export pipelines. Journal of Eurasian studies, 6(2), 107-113. 
Humphrey, C., Skvirskaja, V. (2014). Introduction: The Black Sea as region and horizon. Focaal, 2014(70), 3-11.

Jafarova, E. (2014). Conflict resolution in South Caucasus: Challenges to international efforts. Lexington Books.

Kubicek, P. (2013). Energy politics and geopolitical competition in the Caspian Basin. Journal of Eurasian Studies, 4(2), 171-180.

Maass, A.S. (2016). EU-Russia Relations, 1999-2015: From Courtship to Confrontation. Routledge.

Miskimmon, A., O’Loughlin, B., Roselle, L. (2014). Strategic narratives: Communication power and the new world order. Routledge.

Miskimmon, A., O’Loughlin, B., Roselle, L. (2017). Forging the world: strategic narratives and international relations. University of Michigan Press.

Naghizadeh, A., Farshchi, P., Karimi, D., Mirabbasi, S.B. (2016). Environmental Protection of Caspian Sea by Establishing of Joint Development Zone and Its Effects on Regional and International Security. Journal of Politics and Law, 9(9), 155-161.

Rabiee, H., GharehBeygi, M., Mousavi, S.S. (2015). Hegemony of Iran in the CaspianCentral Asia Region from the perspective of Geopolitical Realities. International Journal of Communication Research, 5(1), 65-73.

Robert, A.M., Letouzey, J., Kavoosi, M.A., Sherkati, S., Müller, C., Vergés, J., Aghababaei, A. (2014). Structural evolution of the Kopeh Dagh fold-and-thrust belt (NE Iran) and interactions with the South Caspian Sea Basin and Amu Darya Basin. Marine and Petroleum Geology, 57, 68-87.

Roselle, L., Miskimmon, A., O'Loughlin, B. (2014). Strategic narrative: A new means to understand soft power. Media, War \& Conflict, 7(1), 70-84.

Saparov, A. (2014). From conflict to autonomy in the Caucasus: the Soviet Union and the making of Abkhazia, South Ossetia and Nagorno Karabakh. Routledge.

Smith, J., Twardowski, A. (2017). The future of US-Russia relations. Center for a New American Security.

Stent, A.E. (2015). The limits of partnership: US-Russian relations in the twenty-first century. Princeton University Press.

Tsygankov, A. (2014). The Limits of Partnership: US-Russian Relations in the TwentyFirst Century. Political Science Quarterly, 129(3), 519-522.

Włodkowska-Bagan, A. (2013). Rywalizacja mocarstw na obszarze poradzieckim. Difin. Zonn, I.S. (2015). Pipeline Architecture of the Black Sea-Caspian Sea Region: Geographical and Political Issues. In Oil and Gas Pipelines in the Black-Caspian Seas Region (pp. 75-83). Springer International Publishing. 